\title{
PELAKSANAAN PENGELOLAAN DAN PEMANTAUAN LINGKUNGAN BERDASARKAN DOKUMEN RKL \& RPL SERTA CORPORATE SOCIAL RESPONSIBILITY (CSR) DI PT. TAMAN NUSA GIANYAR
}

\author{
I Komang Tri Sumandiarta ${ }^{\left.1^{*}\right)}$, IPG Ardhana ${ }^{2)}$, Made Sudiana Mahendra $^{3)}$ \\ ${ }^{1)}$ Program Magister Ilmu Lingkungan Universitas Udayana \\ ${ }^{2)}$ Fakultas MIPA Universitas Udayana \\ ${ }^{3)}$ Fakultas Pertanian Universitas Udayana \\ *Email: sumandiarta_tri@yahoo.com
}

\begin{abstract}
Taman Budaya Nusantara is one of the tourism site that is located in Gianyar which being managed by PT. Taman Nusa. The negative impact from tourism site is an enhancement of environmental destruction. This research aims to analyze the adherence implementation of the Environmental Management Plan document (RKL), Environmental Monitoring Plan document (RPL) and the implementation of CSR Program. The methods that used were in the research are case approachment (The Case Approach), Legislation approachment (The Statue Approach), and Conceptual approachment (Analytical and ConcePT. ual Approach).

The result of the research shows that PT. Taman Nusa did not comply to the terms of legislation according to the implementation of EIA document five aspects, is Permitting, Water Pollution Control, Air Pollution Control, Hazardoces Waste Management and Solid Waste Management. PT. Taman Nusa has fulfilled obligations in carrying out its social responsibility, economic and environment by actualizing the CSR program according to the Article 74 of Constitution No 40 of 2007 about Limited Liability Company (PT). The implementation of CSR program covers 14\% of the total Sidan village.

PT. Taman Nusa Should perform a reparation in managing and controlling the environment according to the rules of constitution which have been suggested by local government through the BLH Gianyar to do some evaluation and reviewing the AMDAL Document of PT. Taman Nusa and conductlinkagemappingof stakeholder sandterritoriesforthe implementation of theoverallCSRprogramin the VillageSidan.
\end{abstract}

Keywords : Environmental Impact Analysis (EIA);Environmental Management Plan (RKL); Environmental Monitoring Plan (RPL); CSR Program

\section{PENDAHULUAN}

Pulau Bali merupakan barometer perkembangan pariwisata nasional yang merupakan daerah tujuan pariwisata Indonesia.Bali konsisten menempatkan sektor pariwisata sebagai sektor andalan.Dampak perkembangan pariwisata terhadap kondisi sosial ekonomi masyarakat lokal dikelompokkan oleh Cohen (1984) dalam Pendit (1994) menjadi delapan kelompok besar, yaitu (1) dampak terhadap penerimaan devisa, (2) dampak terhadap pendapatan masyarakat, (3) dampak terhadap kesempatan kerja, (4) dampak terhadap harga-harga, (5) dampak terhadap distribusi masyarakat atau keuntungan, (6) dampak terhadap kepemilikan dan kontrol, (7) dampak terhadap pembangunan pada umumnya dan (8) dampak terhadap pendapatan pemerintah. Salah satu kabupaten di Bali yang memiliki potensi pariwisata adalah Kabupaten Gianyar. Dari sekian banyak obyek wisata tersebut salah satunya keberadaan Taman Budaya Nusantara "PT. . Taman Nusa". Keberadaan obyek wisata ini bertujuan untuk mendukung pengembangan kepariwisataan di Kabupaten Gianyar. Selain itu, keberadaan sarana pariwisata ini dapat membantu meningkatkan pendapatan dan kesejahteraan masyarakat, membantu aktivitas pembangunan di Kabupaten Gianyar melalui partisipasi, membantu peningkatan pendapatan asli daerah melalui pungutan pajak obyek wisata, serta dapat membantu Pemerintah Daerah Kabupaten Gianyar dalam penyediaan lapangan kerja.

Terlepas dari hal positif di atas, keberadaan prasarana dan sarana kepariwisataan tersebut, selain dapat meningkatkan pendapatan masyarakat juga dapat menimbulkan dampak negatif salah satunya adalah limbah cair yang dihasilkan apabila tidak dikelola dengan baik akan dapat menyebabkan terjadinya penurunan kualitas lingkungan khususnya dampak terhadap penurunan kualitas air sungai.Salah satu upaya yang dapat dilakukan untuk mencegah terjadinya pencemaran lingkungan dilakukan dengan membuat Rencana Pengelolaan dan Pemantauan Lingkungan Hidup yang tertuang dalam Dokumen Analisis Mengenai Dampak Lingkungan (AMDAL). Selain itu, Undang-Undang Nomor 40 Tahun 2007 tentang Perseroan Terbatas menyatakan bahwa "Perseroan harus mempunyai maksud dan tujuan serta kegiatan yang tidak bertentangan dengan ketentuan perundangundangan, ketertiban umum, dan/atau kesusilaan".

Pengawasan terhadap perusahaan dalam 
pelaksanaan dokumen AMDAL khususnya RKL \& RPL serta pelaksanaan tanggung jawab perusahaan dalam bentuk CSR bagi masyarakat sekitar penting untuk dilakukan agar perusahaan benar-benar melaksanakan arahan pengelolaan dan pemantauan lingkungan hidup dalam dokumen AMDAL sehingga tidak hanya dijadikan persyaratan secara administrasi oleh perusahaan dalam pemenuhan perizinan.Berdasarkan hasil pengawasan terhadap pengelolaan lingkungan hidup yang dilakukan oleh Pejabat Pengawas Lingkungan Hidup (PPLHD) BLH Gianyar bekerjasama dengan Pejabat Pengawas Lingkungan Hidup dari Kementrian Negara Lingkungan Hidup pada Semester I Tahun 2014 menunjukkan bahwa PT. . Taman Nusa tidak melaksanakan pengelolaan dan pemantauan lingkungan hidup yang meliputi aspek, pengendalian pencemaran air, pencemaran udara dan pengelolaan limbah Bahan Berbahaya dan Beracun ( $\left.\mathrm{B}_{3}\right)$. Pada saat pengambilan sampel air limbah pada outlet STP dan uji analisa laboratorium, diketahui bahwa kandungan BOD, dan COD dari limbah tersebut melampaui Baku Mutu Air Limbah berdasarkan PerGub Bali Nomor 08 Tahun 2007.

Berdasarkan hal tersebut, maka sangat penting untuk dilakukan evaluasi terhadap ketaatan pelaksanaan dokumen AMDAL khususnya pelaksanaan RKL dan RPL serta CSR di Taman Budaya Nusantara PT. Taman Nusa agar dapat benar-benar melaksanakan pengelolaan dan pemantauan lingkungan serta melaksanakan program CSR dengan baik.

\section{METODOLOGI}

Pendekatan yang digunakan dalam penelitian ini adalah pendekatan kualitatif. Penelitian ini secara detail akan memaparkan keadaan dan kondisi pelaksanaan pengelolaan lingkungan berdasarkan dokumen AMDAL, pelaksanaan pengelolaan lingkungan, dan pelaksanaan Program CSR.Penelitian ini dilaksanakan di Taman Budaya Nusantara PT. . Taman Nusa di Banjar Belahpane, Desa Sidan, Kecamatan Gianyar, Kabupaten Gianyar.Ruang lingkup penelitian dilihat dari (1) Pelaksanaan rencana pengelolaan lingkungan dalam dokumen AMDAL yang telah dimiliki, (2) Kesesuaian antara dokumen Amdal dengan implementasi di lapangan, (3) Pengawasan yang telah dilakukan oleh pemerintah kabupaten Gianyar, (4) Program CSR yang dilaksanakan (5) Peran serta masyarakat, Konstribusi perusahaan, dampak program CSR bagi masyarakat.

Untuk mengetahui pelaksanaan ketaatanoleh perusahaan akan dilakukan pengolahan menggunakan analisis yuridis (Hukum). Aspek Ketaatan yang dinilai meliputi: (1) Aspek Perizinan, (2) Dokumen Lingkungan (3) IPAL (4) Pengendalian Pencemaran Udara (5) Pengelolaan Limbah $\mathrm{B}_{3}$ serta (6) Pelaksanaan program CSR.

\section{HASIL DAN PEMBAHASAN}

\subsection{Dokumen Lingkungan dan Perizinan}

PT. Taman Nusa memiliki dokumen AMDAL yang terdiri dari Dokumen KA-ANDAL, ANDAL, RKL \& RPL serta memiliki Surat Keputusan Kelayakan Lingkungan Hidup (SKKL) yang dikeluarkan oleh Plt. Kepala Badan Lingkungan Hidup Kabupaten Gianyar Nomor: 660.1/176/BLH/ 2013 pada tanggal 8 April 2013. Berdasarkan wawancara dan observasi lapangan yang telah dilakukan PT. . Taman Nusa tidak memiliki Izin Lingkungan, karena pihak PT. . Taman Nusa belum mengajukan permohonan Izin Lingkungan kepada Badan Lingkungan Hidup.

Demikian halnya dengan Izin Pembuangan Limbah Cair (IPLC) ke lingkungan dan Izin Tempat Penyimpanan Sementara (TPS) Limbah Bahan Berbahaya dan Beracun (B) pihak PT. Taman Nusa belum memilikinya karena belum mengetahui tentang perizinan tersebut. Hal ini dibuktikan dengan Dokumen Daftar Periksa Izin Lingkungan (AMDAL atau UKL-UPL) dan Izin PPLH yang menunjukkan bahwa PT. Taman Nusa tidak memiliki izin lingkungan, tidak melaksanakan ketentuan yang tertuang dalam izin lingkungan, dan tidak melaporkan pelaksanaan izin lingkungan sesuai dengan kewajiban penanggung jawab usaha uang diatur dalam UU No 32 Tahun 2009 dan PP No 27 Tahun 1999.

\subsection{PengendalianPencemaran Air}

Hasil wawancara dengan Chief Engineering PT. Taman Nusa (Ahmad yusuf) menunjukkan bahwa selama ini PT. Taman Nusa tidak menyampaikan laporan tentang catatan debit harian dan kadar parameter Baku Mutu Limbah Cair kepada bapedal, gubernur, dan instansi teknis lainnya.

Di samping hal itu, PT. Taman Nusa juga tidak memeriksakan kadar parameter Baku Mutu Limbah Cair secara periodik, juga tidak memasang alat ukur debit atau alir limbah cair dan melakukan pencatatan debit harian limbah cair. Hal ini sejalan Hasil Laporan Pengawasan Penataan Lingkungan yang dilakukan oleh Kementerian Lingkungan Hidup dalam hal ini lembaga yang kompeten melakukan pengawasan adalah Pusat Pengelolaan Ekoregion Bali dan Nusa Tenggara pada 14 Oktober 2014 yang menunjukkan hasil bahwa:

1. Air limbah dihasilkan dari kegiatan kamar mandi, toilet, dapur, dan washtafel.

2. Air limbah yang dihasilkan dari kegiatan dapur diolah dengan sistem biosistem (langsung dibuang ke media lingkungan).

3. Melakukan pengambilan sampling air limbah pada outlet pengolahan air limbah.

4. Pengolahan air limbah yang dihasilkan dari kegiatan toilet, washtafel menggunakan sePT. ictank.

5. Tidak memeriksakan kadar parameter Baku Mutu Limbah Cair secara periodik sekurang- 
kurangnya satu kali dalam sebulan.

6. Tidak memasang alat ukur debit atau alir limbah cair dan melakukan pencatatan debit harian limbah cair.

Hasil laporan pengawasan tersebut menunjukkan bahwa PT. Taman Nusa tidak menaati peraturan yang berlaku berkaitan dengan pengelolaan pengendalian pencemaran air.

\subsection{Pengendalian Pencemaran Udara}

Berdasarkan hasil penelitian diketahui bahwa PT. Taman Nusa tidak melengkapi cerobong genset dengan sarana sampling serta perlengkapan penunjangnya. Sebagaimana dinyatakan oleh I Wayan Yadnya(Chief SecurityPT. Taman Nusa) bahwa PT. Taman Nusa tidak melakukan pengujian kualitas emisi gas buang cerobong genset, uji kualitas udara ambien dan uji tingkat kebisingan serta tidak membuat dan menyampaikan laporan hasil pengujian kualitas emisi gas buang cerobong genset, uji emisi udara ambien, dan uji emisi kebisingan secara periodik kepada Badan Lingkungan Hidup Kabupaten Gianyar.

Kondisi ini didukung dengan laporan yang tercantum dalam Berita Acara Pengawasan Penataan Lingkungan Hidup yang dikeluarkan oleh Pusat Pengelolaan Ekoregion Bali dan Nusa Tenggara yang dilakukan pada Selasa, 14 Oktober 2014.

\subsection{Pengelolaan Limbah Bahan Berbahaya dan Beracun (B3)}

PT. Taman Nusa juga tidak membuat dan menyimpan catatan tentang jenis, karakteristik, jumlah dan waktu dihasilkannya limbah $\mathrm{B}_{3}$ serta menyampaikan laporan kepada badan Lingkungan Hidup Kabupaten Gianyar. PT. Taman Nusa tidak memiliki kontrak kerjasama (MoU) dengan perusahaan yang memiliki izin dari instansi yang berwenang sebagai pemanfaatan $\mathrm{LB}_{3}$, penimbun $\mathrm{LB}_{3}$, pengolah $\mathrm{LB}_{3}$, dan/atau pengumpul limbah $\mathrm{B}_{3}$. Kondisi ini didukung dengan laporan yang tercantum dalam Berita Acara Pengawasan Penataan Lingkungan Hidup yang dikeluarkan oleh Pusat Pengelolaan Ekoregion Bali dan Nusa Tenggara yang dilakukan pada Selasa, 14 Oktober 2014.

\subsection{Pengelolaan Sampah/Limbah Padat}

Berdasarkan karakteristik sampah yang ada di PT. Taman Nusa, salah satu teknik perwadahan yang perlu dikembangkan adalah pewadahan yang kedap air, tidak mudah rusak dan mudah diperoleh. Adapun wadah yang dimaksud dapat berupa wadah permanen, yaitu ditembok dan tong sampah yang dilengkapi dengan penutup wadah sehingga tidak menimbulkan bau. Sebaiknya, tempat sampah yang disediakan harus berbeda untuk tiap jenis sampah. Idealnya sampah basah hendaknya dikumpulkan bersama sampah basah, demikian pula dengan sampah kering, sampah yang mudah terbakar dan sampah yang tidak mudah terbakar, hendaknya ditempatkan pada tempat yang terpisah.

Saat ini pengelola di PT. Taman Nusa belum memikirkan bagaimana mengurangi jumlah timbunan sampah, sehingga sangat dibutuhkan penyuluhan atau mempromosikan metode pemilahan sampah skala lingkungan dengan harapan dapat mengurangi masalah sampah dan juga menurunkan volume pembuangan sampah ke TPA.

\subsection{Pelaksanaan Corporate Social Respon- sibilty (CSR)}

Sejauh ini PT. Taman Nusa tidak pernah mensosialisasikan Program CSR baik secara formal maupun secara nonformal kepada Perbekel Desa Sidan. Hal ini terbukti dari hasil observasi di lapangan yang menunjukkan bahwa seluruh

Tabel 1.Sarana Pendukung Sampling PT. Taman Nusa

\begin{tabular}{lllllll}
\hline No & $\begin{array}{l}\text { Sumber Emisi } \\
\text { Kapasitas }\end{array}$ & \multicolumn{5}{c}{ Sarana Pendukung Sampling } \\
\cline { 2 - 7 } & Lubang Sampling & Flange & Lantai Kerja & Tangga & Pagar & Ket \\
\hline 1 & Genset 1 & TidakAda & TidakAda & TidakAda & TidakAda & TidakAda \\
\hline
\end{tabular}

Sumber: Berita Acara Pengawasan Penataan Lingkungan Hidup PT. Taman Nusa, 2014.

Tabel 2.Limbah $\mathrm{B}_{3}$ yang Dihasilkan PT. Taman Nusa

\begin{tabular}{|c|c|c|c|c|c|}
\hline Jenis Limbah $B_{3}$ & Sumber Limbah & Estimasi Timbulan & Pengelolaan Lanjut & Disimpan di TPS perl & Perlakuan \\
\hline \multicolumn{6}{|l|}{ Limbah $\mathrm{B}_{3}$ Padat } \\
\hline Lampu TL & Publik area, kantor & $1 \mathrm{~kg}$ & Disimpan di gudang MEP & & \\
\hline Accu & Genset & $25 \mathrm{~kg}$ & Disimpan di ruang genset & & \\
\hline
\end{tabular}

Sumber:Berita Acara Pengawasan Penataan Lingkungan Hidup PT. . Taman Nusa, 2014 
masyarakat di wilayah Desa Sidan tidak diikutsertakan dalam kegiatan CSR yang dilaksanakan perusahaan. Dari ketujuh banjar desa tersebut, hanya satu banjar saja yang dilibatkan dalam Program CSR PT. . Taman Nusa, yaitu Banjar Blah Pane Kelod, Sedangkan keenam banjar lain sampai saat ini sama sekali belum mendapatkan perhatian dari PT. Taman Nusa. (Hasil wawancara dengan Perbekel Desa Sidan, Bapak I Made Sukra Suyasa)

Tabel 3. Jumlah Penduduk Desa Sidan Tahun 2015

\begin{tabular}{llcc}
\hline No & Nama Dusun & $\begin{array}{c}\text { Jumlah Kepala } \\
\text { Keluarga }\end{array}$ & Jumlah Jiwa \\
\hline 1 & Banjar Sidan Kelod & 264 & 1317 \\
2 & Banjar Sidan & 228 & 1016 \\
3 & Banjar Jageperang & 103 & 482 \\
4 & Banjar Bukit Sari & 92 & 489 \\
5 & Banjar Dukuh & 101 & 483 \\
6 & Blah Pane Kaje & 163 & 723 \\
7 & Blah Pane Kelod & 147 & 721 \\
\hline & Jumlah & $\mathbf{1 0 9 8}$ & $\mathbf{5 2 3 1}$ \\
\hline
\end{tabular}

Sumber:Perbekel Sidan, 2015

Tabel3menunjukkan jumlah penduduk Desa Sidan yang semestinya menjadi target operasional Program CSR PT. Taman Nusa. Program CSR yang dilaksanakan PT. Taman Nusa hanya menyasar satu dusun banjar, yakni Banjar Blah Pane Kelod, dengan 147 kepala keluarga dan 721 penduduk. Persentase area implementasi Program CSR PT. Taman Nusa tersaji dalam diagram berikut ini.

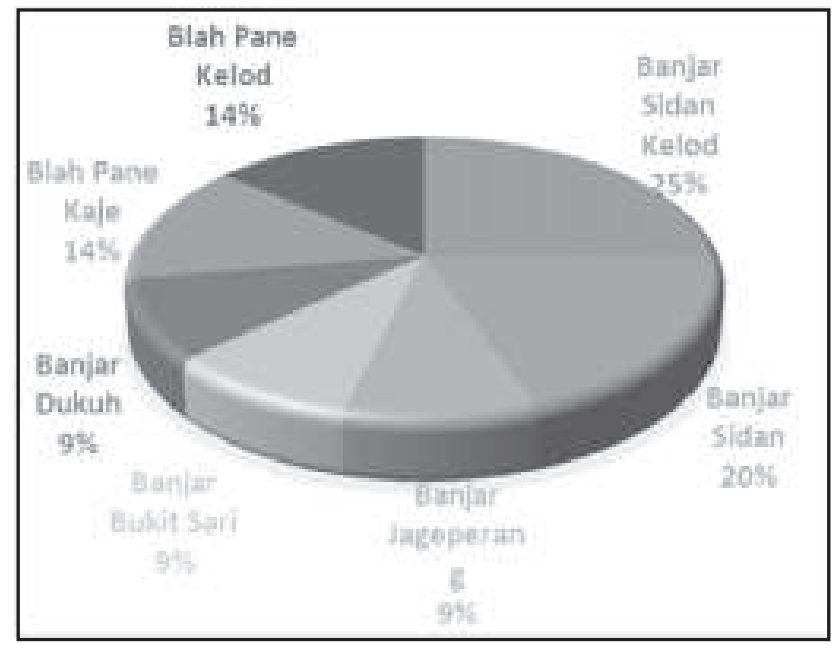

Gambar 2. Diagram Persentase Area Implemetasi Program CSR PT. Taman Nusa

Gambar 2 menunjukkan bahwa realisasi program CSR yang semestinya mencakup seluruh wilayah Desa Sidan, ternyata baru diimplementasikan di satu dusun banjar, yakni yakni Banjar Blah Pane Kelod dengan persentase 14\%. Hal ini menunjukkan bahwa Program CSR yang merupakan sumbangan perusahaan secara tidak langsung terhadap penguatan modal sosial secara keseluruhan, belum berjalan dengan efektif.Program CSR PT. Taman Nusa belum bisa dijadikan sarana untuk memperkuat atau meningkatkan akumulasi modal sosial dalam rangka meningkatkan kesejahteraan masyarakat. Dalam hal ini, perusahaan tidak memberikan perhatian kepada lingkungan sekitar, dengan tidak memberikan mereka berpartisipasi dalam usaha-usaha pelestarian lingkungan demi terpeliharanya kualitas kehidupan umat manusia dalam jangka panjang.

Hal ini diperkuat dengan hasil wawancara dengan salah satu warga masyarakat Blah Pane Kaja yang menyatakan bahwa "Keberadaan PT. Taman Nusa tidak memberikan manfaat bagi masyarakat sekitar, dimana PT. Taman Nusa tidak memberikan kesempatan kerja atau peluang kerja bagi penduduk sekitar". (Hasil Wawancara dengan I Wayan Sukadana, warga Banjar Blah Pane Kaja).

\subsection{Pembahasan}

\subsubsection{Pelaksanaan Dokumen AMDAL}

A. Lingkungan dan Perizinan

Data hasil penelitian ini dilakukan analisis data dengan melakukan analisis yuridis (hukum) terhadap ketaatan pelaksanaan RKL \& RPL serta pelaksanaan CSR di PT. Taman Nusa dengan membandingkan dengan peraturan perundang-undangan yang berlaku. Berdasarkan hasil penelitian diketahui bahwa PT. Taman Nusa memiliki dokumen KAANDAL, ANDAL, RKL \& RPL serta Surat Keputusan Kelayakan Lingkungan Hidup (SKKL) dari Plt Kepala Badan Lingkungan Hidup Kabupaten Gianyar Nomor: 660.1/176/ BLH/2013 pada tanggal 8 April 2013. Berdasarkan ketentuan Pasal 31 UU No 32 Tahun 2009 tentang Perlindungan dan Pengelolaan Lingkungan Hidup yang berbunyi: "Berdasarkan hasil penilaian Komisi Penilai AMDAL Menteri, Gubernur atau walikota menetapkan Keputusan Kelayakan atau Ketidaklayakan Lingkungan hidup sesuai kewenanannya" dan Pasal 32 Ayat 1 PP 27 Tahun 2012 tentang Izin Lingkungan. Seharusnya Keputusan Kelayakan Lingkungan seharusnya dikeluarkan oleh Bupati Gianyar dengan memperhatikan rekomendasi kelayakan lingkungan yang dikeluarkan oleh Komisi Penilai AMDAL.

Selanjutnya telah dilakukan penelusuran dan observasi untuk mendapatkan informasi di Badan Lingkungan Hidup Kabupaten Gianyar yang merupakan sekretariat Komisi Penilai AMDAL (KPA) Kabupaten Gianyar diketahui bahwa pada saat SKKL tersebut ditandatangani pada tahun 2013 tidak ada peraturan perundang- 
undangan di Kabupaten Gianyar baik berupa Perda maupun Pergub yang mengatur adanya pendelegasian kewenangan Bupati Gianyar kepada Kepala BLH Gianyar untuk menandatangani SKKL.

Berdasarkan hal tersebut dapat disimpulkan bahwa SKKL yang dimiliki oleh PT. Taman Nusa tidak sah karena ditandatangani oleh pejabat yang tidak berwenang. Berdasarkan data di Badan Lingkungan Hidup Kabupaten Gianyar didapatkan catatan kronologis penetapan SKKL PT. Taman Nusa tersebut. Diawali dengan verifikasi dan peninjauan lokasi kegiatan oleh tim teknis KPA Kabupaten Gianyar pada tanggal 3 Desember 2012 selanjutnya dilakukan Rapat Komisi Penilai AMDAL Kabupaten Gianyar pada tanggal 9 Januari 2013 dan hasil rapat tersebut telah menolak penilaian AMDAL Pembangunan Taman Budaya Nusantara PT. Taman Nusa.

Berdasarkan hal tersebut diketahui bahwa SKKL ditetapkan tanpa memperhatikan rekomendasi Tim KPA Kabupaten Gianyar dan prosedur penetapannya tidak sesuai dengan Pasal 31 UU Nomor 32 Tahun 2009 serta Pasal 37 Ayat 1 Peraturan Pemerintah Nomor 27 Tahun 2012 tentang Izin Lingkungan. Berdasarkan hasil observasi dan wawancara pihak PT. Taman Nusa menyatakan bahwa pihak perusahaan tidak mengetahui tentang prosedur penetapan AMDAL yang benar sehingga tidak berusaha melakukan sanggahan dan mengikuti prosedur yang diterapkan pada saat penetapan SKKL tersebut. Menindaklanjuti fakta ini maka perlu dilakukan evaluasi secara holistik terhadap proses dan prosedur penetapan AMDAL oleh Pemda Gianyar serta perlu ditetapkan sistem pengawasan dalam pelaksanaan proses dan prosedur penetapan AMDAL tersebut.

PT. Taman Nusa tidak memiliki izin lingkungan, hal ini tidak sesuai dengan ketentuan Pasal 36 ayat (1) Undang Undang Republik Indonesia Nomor: 32 Tahun 2009 tentang Perlindungan dan Pengelolaan Lingkungan Hidup. Pasal 2 ayat (1) dan ayat (2) Peraturan Pemerintah Republik Indonesia Nomor 27 tahun 2012 tentang Izin Lingkungan.

B. Pengendalian Pencemaran Air

PT. Taman Nusa tidak memiliki izin pembuangan air limbah ke air atau sumber airdan/atau pemanfaatan air limbah untuk aplikasi ke tanah. Hal ini melanggar ketentuan: Pasal 20 ayat (3) Undang-Undang Nomor 32 Tahun 2009 Tentang Perlindungan dan Pengelolaan Lingkungan Hidup. Pasal 40 ayat (1) Peraturan Pemerintah Republik Indonesia Nomor 82 Tahun 2001 Tentang Pengelolaan Kualitas Air dan Pengendalian Pencemaran Air.
Pasal 3 ayat (1) Keputusan Menteri Negara Lingkungan Hidup Nomor 142 Tahun 2003 Tentang Perubahan Atas Keputusan Menteri Negara Lingkungan Hidup Nomor 111 Tahun 2003 tentang Pedoman Mengenai Syarat dan Tata Cara Perizinan Serta Pedoman Kajian Pembuangan Air Limbah ke Air Atau Sumber Air. Pasal 13 ayat (1) dan ayat (2) Peraturan Bupati Gianyar Nomor: 55 Tahun 2013 tentang Tata Cara Perizinan Lingkungan yang Berkaitan Dengan Pembuangan Air Limbah Ke Sumber Air Dan perizinan Lingkungan Yang Berkaitan Dengan Pemanfaatan Air Limbah Ke Tanah Untuk Aplikasi Pada Tanah.

Ketidaktaatan, kelalaian, atau pelanggaran atas kewajiban untuk mengendalikan pencemaran lingkungan sebagaimana ditetapkan dalam Undang-Undang tentang Perlindungan dan Pengelolaan Lingkungan Hidup (dan peraturan-peraturan turunannya yang berkekuatan hukum mengikat) diancam dengan sejumlah kemungkinan sanksi, baik sanksi administratif maupun sanksi pidana. Termasuk tentunya kepada mereka yang melakukan pencemaran air. Jalur pidana biasanya baru diberikan apabila bentuk pemberian sanksi administrasi ternyata tidak efektif. Walau demikian sanksi pidana dapat langsung diterapkan apabila tingkat kesalahan pelaku tergolong relatif berat atau akibat perbuatannya dinilai sangat meresahkan masyarakat.

PT. Taman Nusa wajib menyampaikan laporan tentang pelaksanaan upaya pengelolaan air limbahnya (khususnya terhadap bagianbagian yang dipersyaratkan dalam izin) sekurang-kurangnya 3 (tiga) bulan sekali kepada Bupati atau Walikota dengan tembusan disampaikan kepada Gubernur dan Menteri. Saluran pembuangan air limbah harus (a) kedap sehingga tidak terjadi perembesan limbah cair ke lingkungan, (b) memiliki alat ukur debit atau laju alir limbah cair, dan (c) terpisah dengan saluran air hujan. Pemantauan yang harus dilakukan penanggungjawab kegiatan terhadap karakteristik air limbah baku (sebelum IPAL), tingkat produksi bulanan dari kegiatannya, karakteristik air olahan (efluen) IPAL.

PT. Taman Nusa wajib membuat rencana penanggulangan pencemaran air pada keadaan darurat atau keadaan tidak terduga lainnya. PT. Taman Nusa juga wajib melakukan sekaligus membiayai penanggulangan dan pemulihan kondisi air atas pencemaran atau kerusakan yang diakibatkannya. Termasuk juga membayar berbagai ganti rugi atas pencemaran atau kerusakan tersebut. PT. Taman Nusa wajib mengizinkan petugas berwenang untuk memeriksa upaya pengelolaan air limbah yang dilakukannya. 
C. Pengelolaan Limbah Bahan Berbahaya dan Beracun (B3)

PT. Taman Nusa tidak memiliki izin tempat penyimpanan sementara limbah bahan berbahaya dan beracun (TPS $\mathrm{LB}_{3}$ ) hal ini melanggar ketentuan: Pasal 59 ayat (4) UndangUndang Nomor 32 Tahun 2009 tentang Perlindungan dan Pengelolaan Lingkungan Hidup, yang berbunyi. Pasal 3 ayat (2) Peraturan Menteri Negara Lingkungan Hidup Nomor 18 Tahun 2009 tentang Tata Cara Perizinan Pengelolaan Limbah Bahan Berbahaya dan Beracun. Pasal 5 ayat (1) Peraturan Bupati Gianyar Nomor 37 Tahun 2013 tentang Tata Cara Perizinan dan Pengawasan Pengelolaan Limbah Bahan Berbahaya Dan Beracun Serta Pengawasan Pemulihan Akibat Pencemaran Limbah Bahan Berbahaya Dan Beracun. PT. Taman Nusa tidak memiliki tempat penyimpanan sementara limbah bahan berbahaya dan beracun, hal ini melanggar ketentuan:Pasal 59 ayat (1) Undang-Undang Nomor 32 Tahun 2009 Tentang Perlindungan dan Pengelolaan Lingkungan Hidup. Pasal 29 Ayat (1) dan ayat (2) Peraturan Pemerintah Nomor 18 tahun 1999 tentang Pengelolaan Limbah Bahan Berbahaya dan Beracun sebagaimana telah diubah dengan Peraturan pemerintah Nomor 85 tahun 1999 tentang Perubahan Peraturan Pemerintah Nomor 18 Tahun 1999 tentang Pengelolaan Limbah $\mathrm{B}_{3}$. Pasal 5 Keputusan Kepala Badan Pengendalian Dampak Lingkungan Nomor 01 Tahun 1995 tentang Tata Cara dan Persyaratan Teknis Penyimpanan dan Pengumpulan Limbah Bahan Berbahaya dan Beracun.PT. Taman Nusa tidak membuat dan menyimpan catatan tentang jenis, karakteristik, jumlah dan waktu dihasilkannya limbah $\mathrm{B}_{3}$ serta menyampaikan laporan kepada badan Lingkungan Hidup Kabupaten Gianyar dan instansi terkait lainnya; hal ini melanggar ketentuan:Pasal 11 Ayat (1) dan ayat (2) Peraturan Pemerintah Nomor 18 tahun 1999 tentang pengelolaan Limbah Bahan Berbahaya dan Beracun jo Peraturan Pemerintah Nomor 85 Tahun 1999 tentang Perubahan atas Peraturan Pemerintah Nomor 18 tahun 1999 tentang Pengelolaan Limbah $\mathrm{B}_{3 .}$

PT. Taman Nusa tidak memiliki kontrak kerjasama (MoU) dengan perusahaan yang memiliki izin dari instansi yang berwenang sebagai pemanfaatan $\mathrm{LB}_{3}$, penimbun $\mathrm{LB}_{3}$, pengolah $\mathrm{LB}_{3}$, dan/atau pengumpul limbah $\mathrm{B}_{3}$. Hal ini melanggar ketentuan: Pasal 4 ayat (2) Peraturan Menteri Negara Lingkungan Hidup Nomor 18 Tahun 2009 tentang Tata Cara Perizinan Pengelolaan Limbah Bahan Berbahaya dan Beracun.
D. Pengendalian Pencemaran Udara

PT. Taman Nusa tidak melakukan pengujian kualitas emisi gas buang cerobong genset, uji kualitas udara ambien dan uji tingkat kebisingan serta tidak membuat dan menyampaikan laporan hasil pengujian kualitas emisi gas buang cerobong genset, uji emisi udara ambien, dan uji emisi kebisingan secara periodik kepada Badan Lingkungan Hidup Kabupaten Gianyar dan instansi terkait lainnya. Hal ini melanggar ketentuan: Pasal 30 ayat (1) Peraturan Pemerintah Nomor 41 Tahun 1999 tentang Pengendalian Pencemaran Udara. Pasal 50 ayat (1) Peraturan Pemerintah Nomor 41 Tahun 1999 tentang Pengendalian Pencemaran Udara.

E. Pengelolaan Sampah/Limbah Padat

PT. Taman Nusa tidak melakukan pemilahan sampah berdasarkan jenis sampahnya yaitu sampah organik dan sampah anorganik. Hal ini telah sesuai dengan ketentuan pada dokumen RKL \& RPL maupun peraturan perundang-undangan yang berlaku yaitu Undang-Undang Nomor 18 Tahun 2008 tentang Pengolahan Sampah dan Peraturan Daerah Bali Nomor 07 Tahun 2011 tentang Pengolahan Sampah.

\section{F. Pelaksanaan Program CSR}

Definisi CSR secara etimologis kerap diterjemahkan sebagai tanggung jawab sosial dan lingkungan perusahaan. Namun setelah tanggal 16 Agustus 2007, CSR di Indonesia telah diatur dalam Undang-Undang Nomor 40 tahun 2007 tentang Perseroan Terbatas yang mengantikan Undang-Undang Nomor 1 tahun 1995 tentang Perseroan Terbatas. Pasal 74 Undang-Undang nomor 40 tahun 2007 tentang Perseroan Terbatas pada dasarnya telah mengakhiri perdebatan tentang wajib tidaknya CSR atau Tanggung Jawab Sosial dan Lingkungan (TJSL) bagi perusahaan perseroan terbatas. Undang-Undang ini secara imperatif menjelaskan bahwa CSR merupakan sebuah kewajiban hukum bagi perusahaan yang memenuhi kriteria yang ditetapkan undangundang. CSR yang diatur dalam UUPT. 2007 diilhami oleh pandangan yang berkembang belakangan ini yang mengajarkan perseroan sebagai perusahaan yang melakukan kegiatan di tengah-tengah kehidupan masyarakat, maka perusahaan harus ikut bertanggung jawab terhadap masalah-masalah sosial yang dihadapi masyarakat setempat.Dalam Penjelasan Pasal 74 Undang-Undang No. 40 Tahun 2007 tentang Perseroan Terbatas jelas disebutkan bahwa kewajiban pelaksanaan Corporate Social Responsibility (CSR) bagi perusahaan yang 
menjalankan kegiatan usahanya di bidang dan/ atau berkaitan dengan sumber daya alam ini tidak hanya melihat pada bisnis inti (core business) dari perusahaan tersebut. Hal ini berarti bahwa baik itu perusahaan pertambangan, industri perkayuan, industri makanan, yang dalam kegiatan usahanya berhubungan langsung dengan sumber-sumber daya alam, maupun rumah sakit, perusahaan telekomunikasi, perbankan, percetakan dan perusahaanperusahan lain yang walaupun tidak secara langsung menggunakan sumber daya alam dalam kegiatan usahanya, wajib melaksanakan CSR.

Hasil penelitian di lapangan menunjukkan bahwa PT. Taman Nusa telah memenuhi kewajibannya dalam melaksanakan tanggung jawab sosial, ekonomi dan lingkungan dengan melaksanakan sebagian Program CSR sesuai dengan ketentuan Pasal 74 Undang-Undang No. 40 Tahun 2007 tentang Perseroan Terbatas. Tanggung jawab perusahaan bidang sosial ini dilakukan dalam bentuk kegiatan peduli sosial pada saat perusahaan merayakan hari ulang tahunnya berupa pengobatan gratis, penyantunan anak yatim, dan donor darah. Sedangkan tanggung jawab perusahaan bidang ekonomi berupa perekrutan tenaga kerja dari masyarakat sekitar perusahaan sebesar $27 \%$ dari total keseluruhan dan tanggung jawab perusahaan bidang lingkungan dilakukan dengan aksi penanaman pohon yang melibatkan Pemerintah Kabupaten Gianyar dan masyarakat sekitar. Hal ini menunjukkan bahwa PT. Taman Nusa telah memberikan perhatian terhadap kepentingan sosial, ekonomi dan lingkungan di sekitarnya sesuai dengan ketentuan Pasal 74 Undang-Undang No. 40 Tahun 2007.

\section{SIMPULAN DAN SARAN}

\subsection{Simpulan}

1. PT. Taman Nusa tidak taat terhadap ketentuan peraturan perundang-undangan dalam pelaksanaan pengelolaan dan pemantauan lingkungan ditinjau dari dokumen AMDAL dilihat dari aspek: (1) Perijinan, (2) Pengendalian Pencemaran Air, (3) Pengendalian Udara, (4) Pencemaran Limbah $\mathrm{B}_{3}$, serta (5) Pengelolaan Limbah Padat.

2. PT. Taman Nusa melaksanakan program CSR sesuai dengan ketentuan pasal 74 UndangUndang No. 40 tahun 2007 tentang Perseroan Terbatas, dengan persentase sebesar 14\% secara keseluruhan di Desa Sidan. Pelaksanaan program CSR meliputi: (1) Tanggungjawab sosial: santunan anak yatim, donor darah; (2) Tanggungjawab lingkungan: Penanaman pohon; dan (3) Tanggungjawab ekonomi: Perekrutan tenaga kerja dari masyarakat sekitar perusahaan.

\subsection{Saran}

1. PT. Taman Nusa agar memperbaiki prosedur perolehan izin lingkungan ditinjau dari dokumen AMDAL khususnya RKL-RPL agar sesuai dengan peraturan perundang-undangan yang berlaku, serta disarankan kepada Pemerintah Daerah melalui BLH Kabupaten Gianyar bias melakukan evaluasi dan mengkaji kembali serta memperbaiki dokumen AMDAL yang dimiliki PT. Taman Nusa.

2. PT. Taman Nusa agar melakukan linkage stakeholders pemetaan wilayah serta keseluruhan di Desa Sidan untuk membangun kedekatan dan pemahaman berbagai persoalan yang dihadapi masyarakat secara konsektual, serta melakukan evaluasi setiap kegiatan yang sudah dilakukan agar bisa menjadi target pencapaian secara berkelanjutan.

\section{DAFTAR PUSTAKA}

Undang-Undang No. 32 Tahun 2009, tentang Perlindungan dan Pengelolaan Lingkungan Hidup.

No. 40 Tahun 2007 tentang Perseroan Terbatas.

Pendit, N.S. 1994. Ilmu Pariwisata Sebuah Pengantar Perdana. Jakarta, PradnyaParamita.

Peraturan Pemerintah RI No. 41 Tahun 1999, tentang Pengendalian Pencemaran Udara.

No. 82 Tahun 2001, tentang Pengelolaan Kualitas Air dan Pengendalian Pencemaran Air.

. No. 27 Tahun 2012, tentang Izin Lingkungan.

RI No. 81 Tahun 2012, tentang Pengelolaan Sampah Rumah Tangga dan Sampah Sejenis Sampah Rumah Tangga.

Peraturan Menteri Negara Lingkungan Hidup No. 05 Tahun 2012, tentang Jenis Rencana dan/atau Kegiatan Yang Wajib Dilengkapi Dengan AMDAL.

Peraturan Gubernur Bali No. 8 Tahun 2007, tentang Baku Mutu Lingkungan dan Kriteria Baku Kerusakan Lingkungan Hidup.

Keputusan Menteri Negara Lingkungan Hidup No. 07 Tahun 2001, tentang Pejabat Pengawas Lingkungan Hidup Dan Pejabat Pengawas Lingkungan Hidup Daerah.

Menteri Lingkungan Hidup. Surat Keputusan No: Kep-3/1995 tentang Baku Mutu Emisi Sumber Tidak Bergerak.

Keputusan Bupati No. 445 Tahun 2004, tentang Standar Oprasional SOP Pelaksanaan Pengelolaan dan Pemanatuan AMDAL, UKL\&UPL di Kabupaten Gianyar. 